\title{
Sosyal Beceri Geliştirme Sistemi- Derecelendirme Ölçeği (3-5 Yaş Okul Öncesi Versiyonu) Öğretmen Formu: Geçerlik ve Güvenirlik Çalışması
}

\author{
Cansu Tutkun*, Çağlayan Dinçer**
}

Makale Geliş Tarihi:06.10.2018

Makale Kabul Tarihi: 10.11.2019

DOI: $10.35675 /$ befdergi.467864

$\ddot{O} z$

Bu çalışmada Sosyal Beceri Geliştirme Sistemi- Derecelendirme Ölçeği, (3-5 yaş okul öncesi versiyonu) ögretmen formunun geçerlik ve güvenirlik çalışmasının yapılması amaçlanmaktadır. Araştırmanın örneklemini, farklı okul öncesi ĕgitim kurumlarına devam eden 3-5 yaş grubunda 305 çocuğun öğretmeni $(n=28)$ oluşturmaktadır. Verilerin analizinde kapsam geçerliği, doğrulayıcı faktör analizi, test tekrar test güvenirliği ve iç tutarlılık katsayısı (Cronbach alfa) hesaplanmıştır. Kapsam geçerliğinin belirlenmesinde 5 uzmandan görüş alınmış ve ölçekte yer alan 76 maddenin de ölçekte kalması yönünde karar verilmiştir. Doğrulayıcı faktör analizi sonucunda ölçeğin 76 madde ve 12 faktörlü yapısının toplanan verilerle genel olarak uyum sağladĭ̆ belirlenmiştir. Ölçeğin iç tutarlılık katsayılarının .70 ile .86 arasında değiştiği görülmüş̧ür. Bu sonuçlar Sosyal Beceri Geliştirme SistemiDerecelendirme Ölçeği (3-5 yaş okul öncesi versiyonu) Öğretmen Formunun Türkiye'deki çocukların sosyal becerilerini değerlendirmede geçerli ve güvenilir bir araç olduğunu göstermiştir.

Anahtar Kelimeler: Sosyal beceri gelişstirme sistemi- derecelendirme ölçeği, ögrretmen formu, okul öncesi

\section{The Social Skills Improvement System- Rating Scale (3-5 Age Preschool Version) Teacher Form: Validity and Reliability Study}

\begin{abstract}
In this study, it is aimed to conduct the validity and reliability study of the Social Skills Improvement System-Rating Scale (3-5 age preschool version) teacher form. The sample of the research consists of teachers $(n=28)$ of 305 childrenin the 3-5 year old group who continued to different pre-school education institutions. Content validity, confirmatory factor analysis, test retest reliability and internal consistency coefficient (Cronbach alpha) were calculated in the analysis of the data.Five experts were consulted for the content validity and 76 items on the scale were decided by the experts to remain on the scale.As a result of confirmatory factor analysis, it was determined that 76 items and 12 factorial structure of the scale generally comply with the collected data.Internal consistency coefficients of the scale
\end{abstract}

\footnotetext{
"Bayburt Üniversitesi, Eğitim Fakültesi, Temel Eğitim Bölümü, Bayburt, Türkiye, ctutkun@ bayburt.edu.tr, ORCID: 0000-0002-2722-2274

${ }^{* *}$ Hasan Kalyoncu Üniversitesi, Eğitim Fakültesi, Temel Eğitim Bölümü, Gaziantep, Türkiye, fcdincer@gmail.com, ORCID: 0000-0001-5468-9155
}

Kaynak Gösterme: Tutkun, C. ve Dinçer, Ç. (2019). Sosyal beceri geliştirme sistemi- derecelendirme ölçeği (3-5 yaş okul öncesi versiyonu) öğretmen formu: geçerlik ve güvenirlik çalışması. Bayburt Eğitim Fakültesi Dergisi, 14(28), 301-323. https://doi.org/ 10.35675/befdergi.467864 
change between .70 and .86.These results showed thatThe Social Skills Improvement SystemRating Scale (3-5 age preschool version) Teacher Forma reliable and valid tool for measuring social skills of children in Turkey.

Keywords: Social skills improvement system- rating scale, teacher form, preschool.

\section{Giriş}

Günümüzde hem toplumsal yaşamda hem de iş yaşamında, sosyal becerileri yüksek, hızlı değişim ile başa çıkabilecek yeterliliklere sahip ve çevresine uyum sağlayabilen bireylere daha fazla ihtiyaç duyulmaktadır (Broadhead, Johnston, Tobbell ve Woolley, 2010). Bireylerin yaşamında, başkalarının ihtiyaçlarını göz önünde bulundurarak, çevresi ile uyum içinde çalışmasında ve kişisel hedeflerini karşılamasında (Doble, Bonnell ve Magill-Evans, 1991), bağımsız hareket edebilmesinde, yeni ilişkiler geliştirmesinde, toplumdaki konumunu ve rollerini anlamasında (Broadhead vd., 2010), başkalarına yardım etmesinde, haklarını kullanabilmesinde sosyal becerilerin önemi büyüktür. Bireyin içinde yaşadığı toplumun bir üyesi haline gelmesi ve toplumsal sorumluluklarını yerine getirmesi bireyin toplumsal yaşamda gerekli olan sosyal becerileri kazanması ile olanaklıdır (Çubukçu ve Gültekin, 2006). Sosyal beceriler; uyumsal davranışlar olarak tanımlanmakta ve olumlu sosyal ilişkileri başlatma ve sürdürmeyi kolaylaştırma, akran kabulüne ve arkadaşlık gelişimine katkıda bulunma, başarılı bir şekilde okula ve sosyal çevredeki bireylerin isteklerine uyum sağlama ve bunlarla başa çıkma gibi bir dizi yeterliği temsil etmektedir (Gresham, Van ve Cook, 2006; Hupp, LeBlanc, Jewell ve Warnes, 2009). Sosyal beceriler, olumlu etkileşimi destekleyen, aynı zamanda hayal kırıklığına uğratan olumsuz etkileşimlerde uygun sosyal davranışlar sergilenmesini sağlayan, öğrenilmiş davranışlardır (Gresham ve Elliott, 2008). Öğrenme ile ilgili sosyal beceriler, bağımsızlık, sorumluluk, öz düzenleme ve işbirliğinin etki alanlarına girmektedir (McClelland ve Morrison, 2003).

Gelişimin her alanında çok önemli bir unsur olan sosyal becerilerin temeli, çocuğun doğumuyla başlamakta ve özellikle ilk altı yılı kapsayan süreçte atılmaktadır (Berk, 2013; Broadhead vd., 2010). Küçük çocukların sosyalleşmesi, çevrelerindeki dünyanın kurallarını ve beklentilerini anlamalarını sağlamaktadır. Belirli durumlarda hangi davranışların uygun olduğunu, nasıl nazik davranılacağını ve kendilerini nasıl güvende tutacağını öğrenmek, bu öğrenme sürecinin önemli yönleridir; bu kuralları sorgulamak da öğrenmenin önemli bir parçasıdır. Sosyal beceriler, başkalarını dinlemeyi, bir işi sırayla yapmayı, oyuncaklarını paylaşmayı ve işbirlikçi oyunlar oynamalarını kapsamaktadır (Broadhead vd., 2010). Bu dönemdeki çocuklar, pozitif ilişkiler kurup sürdürme, kendi duygularını, düşüncelerini ve davranışlarını yönetme, haklarını savunma ve diğer insanların haklarını ihlal etmeme, diğer insanların değerlerine ve inançlarına saygı gösterme, işbirliği içinde çalışma, sorunları tek başına ya da başka insanlarla çözme, diğer insanlarla empati kurma, kendini motive etme, hedeflere ulaşmayı destekleme, 
problemleri çözme konusunda ısrar etme, sakin ve iyimser kalabilme konularında teşvik edilmelidir (Csóti, 2009).

Çocukların sosyal olarak yeterli kabul edilebilmesi için bazı sosyal becerilere sahip olmaları ve bu becerileri sosyal ortamlarda uygun davranışlarla sergilemesi beklenmektedir (Elliott, Malecki veDemaray, 2001).Bu açıdan sosyal yeterlik, çoğunlukla sosyal davranışları, sosyal kabulü ve sosyal becerileri kapsamaktadır (Haagar ve Vaughn, 1995). Ancak literatürde sosyal beceriler ve sosyal yeterliğin birbirinin yerine kullanılabildiği görülmektedir (Cordier, vd., 2015). Sosyal beceriler ve sosyal yeterlik birbiriyle ilişkili olmasına rağmen (Akkök, 2006), birbirlerinin yerine aynı anlamda kullanılmaması gerekmektedir (Gresham ve Elliott, 2008).Sosyal yeterlik, çocukların davranışsal tepkilerinden ya da sosyal etkileşimlerinden elde ettiği olumlu sonuçların başarısı olarak tanımlanmaktadır (Lim ve Rodger, 2008). Sosyal beceriler ise, bir bireyin sosyal görevi başarıyla tamamlamak için sergilediği belirli bir davranış sınıfıdır. Sosyal görevler, akran grubuna girme, bir konuşmayı başlatma ve sürdürme, arkadaş edinme, akranlarıyla oyun oynama vb. gibi becerileri içermektedir. Sosyal görevler, birbiriyle bağlantılı ve farklı sosyal beceriye sahip davranış biçimlerini gerektirmektedir. Sosyal yeterlilik, ise, belirli kriterler verildiğinde bireyin bir sosyal görevi yeterince yerine getirip getirmediği yargılarına dayalı bir değerlendirme terimidir. $\mathrm{Bu}$ kararlar, bireyin okul, ev, toplum içi gibi doğal ortamlarda etkileşimde bulunduğu sosyal aracılar tarafından yapılmaktadır. Bu kavramsallaştırma göz önüne alındığında, sosyal beceriler belirli durumlarda ve belirli davranışlarda yer alan ve bu davranışların belirli sosyal görevlerin yerine getirilmesinde yetkin ya dayeterli olmadığına dair belirli davranışlardır (Gresham ve Elliott, 2008).

Sosyal becerilerin kullanılmaması ise yaygın olarak sosyal beceri eksikliği ya da yetersizliği olarak tanımlanmaktadır (Hupp vd., 2009). Sosyal beceri yetersizliği olan çocuklar, davranışlarının diğer insanları nasıl etkilediğini fark etmemektedir. Sosyal becerilerdeki yetersizlikler, çocukların arkadaş edinmeyi veya ilişkilerini nasıl sürdüreceğini bilmeyeceği anlamına da gelmektedir. Bu durumdaki çocuklar, kendilerini diğer çocuklardan izole edebilmekte ve sosyal olarak geri çekilebilmektedir (Swale, 2006). Ayrıca sosyal olarak kaygılı, içe kapanık ya da utangaç olan bir çocuk, akran grubundan geri çekilme ve akranla ilgili sosyal becerileri öğrenme firsatlarının yokluğu nedeniyle uygun sosyal davranışları asla öğrenememektedir (Gresham vd., 2006). Çocukların sosyal becerilerdeki yetersizlikleri, onların duygusal gelişimlerini de olumsuz etkilemektedir (Swale, 2006). Sosyal becerilerin buradaki önemli kavramsal özelliği, sosyal beceri edinimi ile performans eksiklikleri arasındaki ayrımdır. Sosyal beceri edinme eksiklikleri, "yapamama" sorunları olarak da tanımlanabilir, yani, çocuk, sosyal beceriyi en uygun koşullar altında gerçekleştiremez. Performans eksiklikleri, çocuğun sosyal beceriyi nasıl gerçekleştireceğini bilmesine rağmen, verilen sosyal becerileri kabul edilebilir seviyelerde gerçekleştirememesi olarak kavramsallaştırılabilir. $\mathrm{Bu}$ tür sosyal beceri eksiklikleri, "yapmama” problemleri olarak düşünülmektedir, yani, 
çocuğun ne yapması gerektiğini bilmesi, ancak sosyal beceriyi gerçekleştirmek istememesidir (Gresham vd., 2006). Sosyal beceriler ve sosyal etkileri olan davranışsal aşırılıklar sosyal davranış türleri olarak tanımlanabilir. Yani, sosyal davranışlar hem uyarlanabilir sosyal becerileri hem de sosyal işlevselliği etkileyen diğer davranışları içermektedir (Hupp vd., 2009). Çocukların sosyal becerilere ilişkin deneyim ve anlayış kazanmaları için yeni şeyler denemeye teşvik edilmeleri gerekmektedir. Bu açıdan gerek anne babalar gerekse de öğretmenler çocukların ihtiyaç duyacakları gerekli sosyal becerileri ve özgüvenlerini kazanmalarına yardımcı olmanın çok önemli bir parçasıdır (Broadhead vd., 2010).

Çocukların sosyal becerileri kazanmalarında ilk rol modelleri anne ve babalarıdır. Çocuklar büyüdükçe, aileleri dışındaki öğretmenleri, arkadaşları gibi daha fazla sayıda insanla iletişim kurmaktadır. Çocuğun yakın çevresinde bulunan kardeşler, akranlar ve öğretmenler gibi sosyal gruplar, bir çocuğun rollerini ve rolle ilgili davranışlarını geliştirmeye yardımcı olmaktadır. Çocukların edindikleri sosyal beceriler, sosyal çevreye katılımlarında önemli bir unsurdur (Csóti, 2009; Lim ve Rodger, 2008). Sosyal katılım, çocukların çeşitli sosyal görevlerle ilgili bir dizi sosyal beceri geliştirmelerini gerektirmektedir (Lim ve Rodger, 2008). Ancak birçok çocuk okul öncesi eğitime, akran reddi, davranış problemleri ve düşük akademik başarı gibi yetersiz sosyal becerilerle başlamaktadır (McClelland, Morrison ve Holmes, 2000). Hem ev hem de okul ortamları farklılık gösterdiğinden, bu ortamların her birinde çocuktan uygun beklentiler ve kurallar değişmektedir. Çocuklardan, ortamlardaki beklenti ve taleplerdeki farklılıkları anlaması ve ortamın kurallarına uyum sağlayacak şekilde davranması beklenmektedir (Hupp vd., 2009). Bu bağlamda çocukların erken dönemlerden itibaren okul içinde ve dışında kurallara saygılı olmayı, olumlu davranışlarda bulunmayı, olumlu ilişkiler geliştirmeyi, zorbalık ve ayrımcılık yapmamayı, önemli yaşam değişiklikleriyle ve problemlerle başarılı bir şekilde başa çıkmayı öğrenmeleri, girişimci davranışlar ve özgüven geliştirmeleri gerekmektedir (Csóti, 2009).

Birçok çocuk, haftada beş gün, günde on saat olmak üzere zamanlarının birçoğunu okul öncesi eğitim ortamında geçirmektedir (Mathieson, 2005). Çocuklar okul öncesi eğitim kurumlarında, akranlarına daha fazla ilgi duymaya ve arkadaşlığın ne olduğunu keşfetmeye başlamaktadır. Farklı sosyal davranışlar gösterebilmekte ve akranlarıyla giderek daha fazla konuşabilmekte, onlarla işbirliği yapabilmekte ve paylaşabilmektedirler. Davranışlarının başkalarını nasıl etkileyebileceğini ve diğer insanların davranışlarının onları nasıl etkilediğini anlamaya başlamaktadırlar (Broadhead vd., 2010). Öğretmenlerin çocukların sosyal becerileri ediniminde, problemlerine çözüm bulmalarında önemli bir konumdadırlar. Çocuklara kurallara uymayı, işbirliği yapmayı, dinleme becerileri edinmeyi, problemlerine uygun çözüm yolları bulmayı öğretme gibi görevleri bulunmaktadır. Okul öncesi öğretmenleri sayesinde çocuklar, ilişkiler ve sosyal davranışlar hakkında bilgi sahibi olmaktadır (Mathieson, 2005). Ancak bu süreç, çocukların sahip olduğu deneyimlere bağlı olmakta, bazı çocuklar sosyal becerileri 
sergilemekte zorlanmakta ve sosyal becerileri geliştirme firsatları olmadığ için daha fazla desteğe ihtiyaç duyabilmektedir. Öğretmenlerin, çocukların ihtiyaç duydukları sosyal becerileri geliştirmelerine yardımcı olmak, işbirliği ve paylaşımı destekleyen faaliyetler sağlamak için zaman ayırmaları (Broadhead vd., 2010); okullar ve öğretmenlerin çocuklardan beklentilerini ve müfredatlarını, çocukların farklı ihtiyaçlarına uyacak şekilde adapte etmeleri gerekmektedir (McClelland ve Morrison, 2003). Ayrıca çocukların sosyal becerilerini geliştirmelerine yardımcı olmak için, tüm okul personelinin, uygun davranışlar sergilemeleri önemlidir(Csóti, 2009). Bu açıdan çocuğun yakın çevresinde bulunan anne baba ve öğretmenlerin, çocuğa doğru bir rol model olmalarının, çocuğun sosyal becerileri ediniminde çok önemli katkıları olduğu söylenebilir.

Bununla birlikte, sosyal becerilerin değerlendirilmesi ve eğitilmesinin önemi genellikle eğitimciler tarafından dikkate alınmamaktadır. Çoğu yetişkin, çocukların kibarca iletişim kurduğunu, anlaşmazlıkları dostane bir şekilde müzakere ettiklerini ve yönergelere saygılı bir şekilde uyduğunu görmek istemektedir. Ancak bunlar genellikle eğitim programında karşılaşılan konular olmamaktadır. Eğitim sisteminde yetişkinler, çocuklardan daha çok akademik başarıya ilişkin beklenti içerisine girmekte,ancak sosyal becerilerin yardım ve yönlendirmesi olmaksızın çocukların akademik başarı elde etmeleri mümkün olamamaktadır. Oysaki öğretmenlerin, çocukların sosyal becerilerini geliştirmek için bu becerileri öğretmeleri ve sürdürmeleri gerekmektedir (Luiselli, McCarty, Coniglio, Zorilla-Ramirez ve Putnam, 2005). Okul öncesi öğretmenleriyle yapılan bir araştırmada, çocukların sosyalleşmesi için öğretmenlerin kendilerinin çok fazla bir rolü olmadığını düşündükleri ve sosyal becerilerde kendilerini aracı olarak görmedikleri saptanmıştır (Cooper ve Farran, 1988). Leff ve Lakin (2005), saldırgan davranışların sıklıkla gözlemlendiği okullarda, okuldaki uygulamaların çok önemli bir unsur olduğunu belirtmektedir. Brophy-Herb, Lee, Nievar ve Stollak (2007) ise, okul öncesi dönemde olumlu bir sınıf ortamının, öğretmen davranışları ve çocukların sosyal yeterlilikleri arasındaki ilişkiye dayandığını ifade etmektedir. Bu bağlamda öğretmenlerin ve okul öncesi eğitim kurumlarının, çocukların uygun sosyal becerilerini destekleme ve geliştirmedeki önemlerinin göz ardı edilmemesi gerektiği düşünülmektedir.

Öğretmenler, sınıflarındaki her bir çocuğun, bireysel kişilik özelliklerini, beğenilerini, isteklerini, korkularını, kaygılarını, güçlü ve güçsüz yanlarını tanıması gerekmektedir (Mathieson, 2005). Öğretmenlerin çocukların bireysel özelliklerini ve var olan sosyal becerilerinin farkına varması, çocukların bu becerilerinin geliştirilmesinde önemlidir. Bu sayede öğretmenlerin çocuklardan beklentileri ile çocukların becerileri arasında koordinasyon sağlanarak, çocukların becerilerinin gelişimi teşvik edilebilmektedir (McClelland ve Morrison, 2003). Öğretmenler çocukların sosyal becerileri hakkında bilgi sahibi olduklarında, çocukların gelişimsel ihtiyaçlarını anlama ve çocukları destekleme konusunda daha yetkin hale gelmektedirler (Broadhead vd., 2010). 
Çocukların sosyal becerilerini değerlendirmede doğrudan ve dolaylı ölçümler yapılabilmektedir. Doğrudan değerlendirme gözlem ve kendini izleme stratejilerini; dolaylı değerlendirme ise, rol oynama, görüşmeler, öğretmen ve ebeveyn derecelendirmelerini içermektedir (Cheung, Siu ve Brown, 2017; Luiselli vd., 2005). Akran derecelendirmeleri ve / veya aday gösterimleri, diğer bir ifadeyle sosyometri, akranları derecelendirme veya diğer davranışsal özelliklere göre diğer çocukları aday gösterme gibi teknikler de kullanılarak, çocuğun sosyal becerilerinin sınıftaki diğer çocuklarınkiyle göreceli bir karşılaştırmasını sağlamaktadır (Hupp vd., 2009; Warnes, Sheridan, Geske ve Warnes, 2005). Akranlarla ilişkili olarak, öğretmenler çocuklarla sınırlı bir bağlamda etkileşime girmekte ve genellikle dolaylı olarak çocukların akran etkileşimlerinde yer almaktadır. Akranlar ise birden fazla durum ve ortamdaki diğer çocuklarla daha fazla temas ve etkileşime sahip oldukları için diğer çocukları gözlemleme fursatlarına da daha fazla sahip olmaktadırlar (Kwon, Kim ve Sheridan, 2012). Bu bağlamda sosyometri, çocukların sosyal becerilerini değerlendirmede uygun yöntemlerden biri olarak kabul edilmektedir. Çocukların sosyal becerilerini değerlendirmede kullanılan diğer bir teknik de öz değerlendirmedir. Bu teknik, bir çocuğun kendi sosyal davranışları ve ilişkileri hakkındaki düşüncelerini ve görüşlerini bildirmesini gerektirir. Çocuklardan ayrıca, çeşitli sosyal durumları veya etkileşimleri nasıl ele alacaklarını bildirmeleri istenebilir. Her ne kadar öz raporlar, çocuğun kendi sosyal davranışlarına ilişkin algılarına dair benzersiz bilgiler sunsa da, bu tekniğin öznel doğası ölçütle ilgili geçerliliği engellemektedir ve bu nedenle sosyal becerileri değerlendirmek için tek başına bir yöntem olarak kullanılmamaktadır (Hupp vd., 2009; Warnes vd., 2005). Sosyal becerileri değerlendirmede kullanılan davranış gözlemleri, belirli davranış kategorilerini tanımlayan gözlemsel bir kodlama sistemi kullanarak gözlemcilerin, bir çocuğun davranışını belirli bir süre zarfında gözlemleyip kaydetmesini içermektedir. Davranışsal gözlem, doğal bir ortamda gerçekleştirildiğinde, çocuğun repertuarındaki sosyal davranışların sıklık ve çeşitliliğinin anlaşılmasını sağlamaktadır (Hupp vd., 2009; Merrell, 2001; Warnes vd., 2005). Bu tür gözlem tekniğinin bazı sınırlılıkları bulunmaktadır çünkü zaman alıcıdırlar, kapsamlı bir eğitim gerektirirler ve güvenilir ölçüm için çok sayıda gözlem gereklidir (Lim ve Rodger, 2008).

Çocukların sosyal becerilerini değerlendirmede sıklıkla kullanılan yöntemlerden biri de standartlaştırılmış ölçme araçlarıdır (Gresham ve Elliott, 2008). Bu ölçme araçları, öğretmenlerin ve / veya ebeveynlerin çocukları belirli ölçütlere göre derecelendirmelerini gerektirmektedir. Bir çocuğun bireysel sosyal davranışları hakkında bilgi sağlamanın yanı sıra, bu ölçeklerin çoğu standartlaştırılır ve çocuğun davranışının aynı yaştaki norm grubununkiyle karşılaştırılmasına olanak tanımaktadır (Hupp vd., 2009; Kwon vd., 2012; Merrell, 2001; Warnes vd., 2005). Davranış derecelendirme ölçeklerinin avantajları arasında; bilginin ölçülebilir olması, güvenilirlik ve geçerlilik analizlerine uygun olması, örneğin sosyal beceriler ve problem davranışlar gibi geniş çerçevedeki davranışların değerlendirilebilmesi, birden çok bakış açısı (öğretmenler, ebeveynler, öğrenciler) ve davranışları 
değerlendirmek için birden çok puanlayıcı tarafından kullanılabilmesi ve normatif verilerle, bir bireyi diğer bireylerin temsili örnekleri ile karşılaştırarak davranışın şiddetini değerlendirmek için bir standart sağlaması yer almaktadır (Gresham ve Elliott, 2008).

Sosyal becerileri ölçmek için tasarlanan değerlendirme araçlarının birçoğu, zihinsel bozukluğu veya duygusal sorunları olan bireyler için geliştirilmiştir. Bu açıdan sosyal becerileri değerlendiren araçların geliştirilmesinin önemi vurgulanmaktadır (Doble vd., 1991). Sosyal becerileri değerlendirmek amacıyla kullanılan ölçme araçlarını değerlendiren bir çalışmada toplam 53 ölçme aracı incelenmiştir. Bu ölçeklerden 40 ölçme aracı çeşitli sebeplerle (24 ölçek 1994 yılından önce geliştirildiği, 6 ölçek çocuklara spesifik tanı koymada kullanıldığı, 10 ölçek ise sosyal beceri tanımını tam olarak karşılamadığı için) inceleme dışı bırakılmıştır. Araştırma sonucunda çocukların sosyal becerilerini değerlendirmede 13 ölçeğin sıklıkla kullanıldığı sonucuna ulaşılmıştır. Bu ölçeklerden 11 'inin okul çağındaki çocuklara ve ergenlere yönelik geliştirildiği, iki ölçeğin ise 2-5 yaş arası çocukların sosyal becerilerini değerlendirmek amacıyla kullanıldı̆̆ı belirlenmiştir (Cordier, vd., 2015). Bu açıdan özellikle okul öncesi dönemdeki çocukların sosyal becerilerini değerlendirmeye yönelik ölçme araçlarının gerekliliği dikkat çekmektedir.

Sosyal becerilere ilişkin yapılan araştırmalar incelendiğinde; sosyal beceriler ve akademik başarı (Aydoğan, Metin, Büyüköztürk, Mercan ve Kavak, 2017; Kettler, Elliott, Davies ve Griffin, 2011); çocukların kendini yönetme davranışları (Güral, Sezer, Güven ve Efe Azkeskin, 2013); kendilerine güven kazanmaları (Broadhead vd., 2010); problem davranışları (Aydoğan vd., 2017); sosyal yeterlilikleri (BrophyHerb vd., 2007); dil gelişimi (Broadhead vd., 2010), okul başarısı (McClelland ve Morrison, 2003) arasında ilişki bulunduğu saptanmıştır. Schaefer, Shur, MacriSummers ve MacDonald (2004) tarafindan yapılan araştırmada çocukların erken öğrenme becerileriyle sosyal beceriler arasında olumlu yönde bir ilişki, problem davranışları arasında ise olumsuz bir ilişki olduğu görülmüştür. Problem davranışların çocukların erken öğrenme becerilerini olumsuz yönde etkilediği sonucuna ulaşılmıştır (Schaefer vd., 2004). Ayrıca başka bir araştırmada çocukların uzun süre televizyon izlemelerinin sosyal becerilerini olumsuz yönde etkilediği saptanmıştır (Güral ve Önder, 2015). Diğer taraftan sosyal becerilerin, ailesel faktörler, sosyo kültürel değişkenler ve okula geçişte uyuma etkisi bulunduğu belirtilmektedir (McClelland, Morrison ve Holmes, 2000). Bu bilgilere göre sosyal becerilerin çocukların gelişiminde çok önemli olduğu ve çocukların gerek erken öğrenme becerileri gerekse de akademik başarılarını artırdığı, problem davranışlarını azalttığı, çocukların öz güvenlerini olumlu yönde etkilediği söylenebilmektedir.

Bu bağlamda, çocukların sosyal beceri ve problem davranışlarını değerlendirmek üzere bir ölçme aracının ülkemizde erken çocukluk eğitimi alanına kazandırılmasının, bu ölçme aracıyla çocukların sosyal beceri ve problem 
davranışlarının değerlendirilmesinin, bu değerlendirmelere yönelik olarak çocuklara gerekli desteğin sağlanmasının önem taşıdığı düşünülmektedir. Bu noktalardan hareketle de araştırmada, Sosyal Beceri Geliştirme Sistemi- Derecelendirme Ölçeği, (3-5 yaş okul öncesi versiyonu) öğretmen formunun geçerlik ve güvenirlik çalışmasının yapılması amaçlanmaktadır.

\section{Yöntem}

\section{Örneklem}

Araştırmanın örneklemini, seçkisiz atama yoluyla atanan 14 ilkokul bünyesindeki anasınıfı ve 4 bağımsız anaokulu olmak üzere toplam 18 okul öncesi eğitim kurumuna devam eden 3-5 yaş grubundaki 305 çocuğun öğretmenleri $(\mathrm{n}=28)$ oluşturmaktadır. Örneklemde yer alan çocukların 145'i (\%47,5) erkek, 160'1 $(\% 52,5)$ kızdır. Çocukların yaşı açısından 3 yaş grubunda $22(\% 7,2), 4$ yaş grubunda $77(\% 25,2)$ ve 5 yaş grubunda $206(\% 67,6)$ çocuk bulunmaktadır. Öğretmenlerin meslekteki hizmet yılları açısında ise $12(\% 42,8)$ öğretmen 1-5 y1l, 7 öğretmen (\%25) 6-10 yıl ve 4 öğretmen $(\% 14,3) 10$ yıldan fazla öğretmenlik mesleğini yapmaktadır.

\section{Veri Toplama Aracı}

\section{Sosyal beceri geliştirme sistemi- derecelendirme ölçeği}

Sosyal Beceri Geliştirme Sistemi-Derecelendirme Ölçeği (SBGS-DÖ), Gresham ve Elliott tarafindan 1990 yllında geliştirilen Sosyal Beceri Derecelendirme Sistemi'nin (SBDS) önemli ve kapsamlı bir revizyonudur. SBDS, kapsamlı ve başarılı bir şekilde 20 yıldan fazla bir süredir çocukların sosyal becerileri ve problem davranışlarını değerlendirmek amacıyla kullanılmaktadır. SBGS-DÖ, SBDS'de olduğu gibi, çocukların sosyal davranışlarını etkileyen öğretmen-çocuk ve ebeveynçocuk ilişkisi, akran kabulü ve akademik performansın değerlendirilmesinde kullanılmaktadır. SBGS-DÖ'ye, SBDS'de olmayan 4 farklı alt boyut eklenmiştir. Bu alt boyutlar; katılım, zorbalık, hiperaktivite / dikkatsizlik ve otizm spektrumudur. 35 yaş arası çocuklar için ölçümler güçlendirilmiştir. SBDS'de yer alan 3'lü likert tipi ölçek yerine SBGS-DÖ'de 4'lü likert tipi ölçüm yapılarak ölçeğin psikometrik özellikleri geliştirilmiştir. SBGS-DÖ, çocukların sosyal becerilerinin incelenmesi, sınıflandırması, müdahale programlarının planlanması ve sonuçların değerlendirilmesiyle ilgili karar verirken yararlı bir ölçme aracı olarak kullanılmaktadır (Gresham ve Elliott, 2008).

SBGS-DÖ'nün revize edilmesinde öncelikle içeriğin geliştirilmesine ilişkin çalışmalar yapılmıştır. Bu amaçla, SBDS'de yer alan sosyal beceriler ve problem davranışlar ölçeklerinin maddelerinin genişletilmesine karar verilmiştir. Yaklaşık olarak \%90'nı yeni olan 400'den fazla madde havuzu oluşturulmuştur. Maddeler incelenirken öğretmen ve anne babaların okuma yeteneklerinin birbirinden farklı olduğu kriteri göz önünde bulundurularak maddelerin kısa ve kolay anlaşılır 
olmasına dikkat edilmiştir. Ölçeğin standardizasyon çalışmaları Eylül 2006 ve Ekim 2007 tarihleri arasında gerçekleştirilmiştir. Standardizasyon için veriler ülke çapında yaşları 3 ila 18 arasında değişen 4.700 çocuğa yönelik, 115 bölge ve 36 eyaletten toplanmıştır. Standardizasyon çalışmaları sırasında çeşitli geçerlik ve güvenirlik çalışmaları da yapılmıştır. Ölçeğin güvenirliğini sağlamak amacıyla iç tutarlılık katsayısı SBGS-DÖ’de yer alan tüm ölçekler, alt ölçekler, formlar, yaş grupları ve norm gruplarına göre hesaplanmıştır. Güvenirliği sağlamak amacıyla ayrıca test tekrar test ve değerlendiriciler arası güvenirlik katsayıları analiz edilmiştir. Geçerlik çalışmalarında ise yakınsama ve ıraksama geçerliği hesaplanmış, SBGS-DÖ’nün diğer ölçeklerle ilişkisi değerlendirilmiş ve kanıta dayalı odak klinik gruplarda çalışmalar yapılmıştır (Gresham ve Elliott, 2008).

Sosyal Beceri Geliştirme Sistemi- Derecelendirme Ölçeği, okul öncesi (3-5 yaşlar aras1), ilkokul (6-12 yaşlar arası) ve orta öğretim (13-18 yaşlar arası) dönemindeki çocuklar için kullanılabilmektedir. SBGS-DÖ, değerlendiriciler tarafından yaklaşık 15-20 dakikada doldurulmaktadır. SBGS-DÖ, sosyal beceri, problem davranışlar ve akademik başarı olmak üzere üç alanda değerlendirme yapmaktadır. Tüm formlar, aşağıdaki alt alanlardaki ortak sosyal becerileri içermektedir: iletişim, işbirliği, kendini ifade etme, sorumluluk, empati, katılım ve öz denetim. Problem Davranışlar ölçeği dışsallaştırma, zorbalık, hiperaktivite / dikkatsizlik, içselleştirme ve otizm spektrumunu içermektedir. SBGS-DÖ, öğretmen formunda, çocukların akademik başarılarını ölçmek amacıyla Akademik Yetkinlik ölçeği de bulunmaktadır. Akademik Yetkinlik ölçeği öğretmenlere, öğrencilerin okuma, matematik, motivasyon, ebeveyn desteği ve genel bilişsel işlevlerdeki performansını değerlendirme firsatı sunmaktadır. Ancak SBGS-DÖ, öğretmen formu 3-5 yaş okul öncesi versiyonunda Akademik Yetkinlik ölçeği kullanılmamaktadır (Gresham ve Elliott, 2008).

SBGS-DÖ'de, sıklık ve öneme dayanan iki tip ölçüm kullanılmaktadır. Her Sosyal Beceri ve Problem Davranışları ölçeğinin sıklığı 4'lü likert tipi ölçekle, Sosyal Beceri ölçeğinde yer alan her bir maddenin önemi 3'lü likert tipi bir ölçek kullanılarak derecelendirilmektedir. Sıklığa dayanan ölçümlerde, çocukların her bir sosyal beceri ve problem davranışı, hangi sıklıkta yaptığına karar verilmesi ile doldurulmaktadır. Eğer çocuk bir davranışı hiç yapmıyorsa "asla”, bazen yapıyorsa "nadiren", çoğunlukla yapıyorsa "sıklıkla" ve nerdeyse her zaman yapıyorsa "her zaman" işaretlenmektedir. 4'lü likert tipi bu ölçekte çocukların sosyal beceri ve problem davranışları sergilediği sıklık ölçülmektedir. Ayrıca, SBGS-DÖ, Sosyal Beceri Ölçeği ile davranışın sıklığının değerlendirilmesinin yanı sıra, ölçekteki her sosyal davranışın çocukların gelişimi ve sınıf başarısı için önemi açısından da değerlendirme yapılabilmektedir. Bir davranışın ne kadar önemli olduğunu belirlemek için, eğer o davranış sınıf başarısı ya da çocukların gelişimi için önemli değilse "önemli değil”", önemli ise "önemli”, çok önemli ise "çok önemli” olarak derecelendirilmektedir (Gresham ve Elliott, 2008). 


\section{SBGS-DÖ ğretmen Formu (3-5 yaş okul öncesi versiyonu)}

Bu araştırmada kullanılan SBGS-DÖ'nün okul öncesi dönem (3-5 yaş) öğretmen formu 76 maddeden ve 2 ölçekten (Sosyal Beceri Ölçeği (SBÖ)- Problem Davranışlar Ölçeği (PDÖ) oluşmaktadır. Birinci ölçek 46 maddeden oluşan "Sosyal Beceri Ölçeği"dir ve 7 alt boyuttan oluşmaktadır. Alt boyutlar, iletişim, işbirliği, kendini ifade etme, sorumluluk, empati, katılım ve öz denetimdir. "Iletişim" alt boyutu; "Uygun bir ses tonuyla konuşur.", "Karşıllklı konuşmalarda sırasını bekler." gibi maddeleri içermekte; sırasını bekleme, konuşma sırasında göz kontağı kurma, uygun ses ve mimikler kullanma, teşekkür ederim ve özür dilerim gibi nazik kelimeler kullanma gibi becerileri kapsamaktadır. "İşbirliği" alt boyutu; "Yönergelerinizi takip eder.", "Sinıfta uygun katılım gösterir." gibi maddeleri içermekte; başkalarına yardım etme, materyallerini paylaşma ve yönergelere ve kurallara uyma gibi becerileri kapsamaktadır. "Kendini ifade etme" alt boyutu; "Yetişkinlerden yardım ister.", "Adil olmayan kuralları sorgular." gibi maddeleri içermekte; kendi kendini tanıtabilme, başkalarından bilgi isteme, başkalarının hareketlerine yanıt verme gibi davranışı başlatma becerilerini kapsamaktadır. "Sorumluluk" alt boyutu; "Kendi hareketlerinin sorumluluğunu alır.", "Başkalarıyla birlikteyken sorumlu davranır." gibi maddeleri içermekte; başkalarının işini ya da eşyalarını önemseme, yetişkinlerle iletişiminde sorumlu davranma gibi becerileri kapsamaktadır. "Empati" alt boyutu; "Başkalarını rahatlatmaya çalışır.", "Başkalarını affeder." gibi maddeleri içermekte; başkalarının duygularına ve bakış açılarına ilgi ve saygı gösterme gibi becerileri kapsamaktadır. "Katılım" alt boyutu; "Başlamış olan etkinliklere katılır.", "Başkaların etkinliklere katılmaya davet eder." gibi maddeleri içermekte; süreç içerisinde etkinliklere katılma, iletişimi başlatma, arkadaş olma ve başkalarıyla iyi etkileşimler kurma gibi becerileri kapsamaktadır. "Öz denetim" alt boyutu; "Alay edildiğinde sakinliğini korur.", "Eleştiriyi üzülmeden kabul eder." gibi maddeleri içermekte; çatışma durumlarında (örneğin aynı fikirde olmama, alay etme gibi) ve çatışma olmayan durumlarda (sıra bekleme, anlaşmaya varma gibi) uygun bir şekilde yanıt verme gibi becerileri kapsamaktadır (Gresham ve Elliott, 2008).

İkinci ölçek ise, 30 maddeden oluşan "Problem Davranışlar Ölçeği”dir ve 5 alt boyuttan oluşmaktadır. Alt boyutlar; dişsallaştırma, zorbalık, hiperaktivite/dikkatsizlik, içselleştirme ve otizm spektrumudur. "Dışsallaştırma" alt boyutu; "Düşünmeden davranır.", "Oyunlarda ya da etkinliklerde hile yapar." gibi maddeleri içermekte; fiziksel ve sözel olarak saldırgan davranışlar gösterme, sinirini kontrol etmede başarısız olma gibi problem davranışları kapsamaktadır. "Zorbalık" alt boyutu; "Başkalarını korkutacak şeyler yapar.", "Başkalarına zorbalık yapar." gibi maddeleri içermekte; birilerini zorlayarak bir şeyler yapmasını isteme, birilerini duygusal ya da fiziksel olarak incitme ve başkalarının etkinliğe katılmasına izin vermeme gibi problem davranışları kapsamaktadır. "Hiperaktivite/ dikkatsizlik" alt boyutu; "Dikkatsizdir.", "Kolayllkla dikkati dă̆gllır." gibi maddeleri içermekte; aşırı bir şekilde hareket etme, dürtüsel davranma ve kolaylıkla dikkatinin dağılması 
gibi problem davranışları kapsamaktadır. "IÇselleştirme” alt boyutu; "Üzgün ya da depresif davranır.”, "Başkalarının yanında endişeli davranır." gibi maddeleri içermekte; endişeli, üzgün ve yalnız hissetme, düşük öz saygı sergileme gibi problem davranışları kapsamaktadır. "Otizm spektrumu” alt boyutu; "Aynı şeyleri defalarca tekrarlar.”, "Etkileşimde garip fiziksel jestler kullanır.” gibi maddeleri içermekte; akranlarıyla etkileşiminin zayıf olması, konuşmanın bir parçası olamama, göz kontağı kurmama, garip fiziksel mimikler kullanma, rutinler değiştiğinde üzülme gibi problem davranışları kapsamaktadır (Gresham ve Elliott, 2008).

\section{Uygulama}

Veri toplama sürecinde öncelikle, Milli Eğitim Bakanlığından, Sosyal Beceri Geliştirme Sistemi- Derecelendirme Ölçeğinin (SBGS-DÖ) (TheSocialSkillsImprovementSystem- RatingScale (SSIS-RS)geçerlik ve güvenirlik çalışmasının yapılabilmesi için gerekli izinler alınmıştır. Araştırma yapılacak okulların yöneticileri ve öğretmenlerine araştırma hakkında bilgi verilmiştir. SBGSDÖ, araştırmaya dahil edilen çocukların öğretmenleri tarafından doldurulmuştur. Öğretmenlerin çocukla en az iki ay yaşantıya sahip olmalarına dikkat edilmiştir. 30 çocuk için 7 öğretmen ilk uygulama gerçekleştirildikten üç hafta sonra SBGSDÖ’yü tekrar doldurmuşlardır.

\section{Verilerin Analizi}

Verilerin analizinde doğrulayıcı faktör analizi için LİSREL programı, diğer analizlerde ise SPSS programı kullanılmıştır. Öncelikle ölçeğin kapsam geçerliği için Kapsam Geçerliği Oranı (KGO) ve Kapsam Geçerlik İndeksi (KGİ) belirlenmiştir. $\mathrm{Bu}$ amaçla 5 farklı uzmandan görüş alınmıştır. $\mathrm{Bu}$ incelemenin ardından ölçeğin faktör yapısının doğrulanıp doğrulanmadığı birinci düzey doğrulayıcı faktör analizi (DFA) LISREL programı yardımıyla incelenmiştir. Doğrulayıcı faktör analizi (DFA), pek çok gözlenebilir değişkenin oluşturduğu faktörlerden (gizil değişkenlerden) oluşan faktöriyel bir modelin gerçek verilerle ne derece uyum gösterdiğini değerlendirmeyi amaçlamaktadır. İncelenecek model, ampirik bir çalışmanın verileri kullanılarak belirlenmiş ya da belirli bir kurama dayandırılarak kurgulanmış bir yapıyı tanımlayabilmektedir (Sümer, 2000). DFA'da modelin geçerliliğini değerlendirmek için çok sayıda uyum indeksi kullanılmaktadır. Bunlar içinde en sık kullanılanları (Cole, 1987; Sümer, 2000); Ki-Kare Uyum Testi (Chi-SquareGoodness, $\chi 2$ ), Yaklaşık Hataların Ortalama Karekökü (RootMeanSquareError of Approximation, RMSEA), Karşılaştırmalı Uyum İndeksi (ComparativeFıt Index, CFI), Normlaştırılmamış Uyum İndeksi (Non-Normed Fit Index, NNFI), Normlaştırılmış Uyum İndeksi (Normed Fit Index, NFI), İyilik Uyum İndeksidir (Goodness of Fit Index, GFI). Ölçek modelinde gözlenen değerlerin $\mathrm{X} 2 / \mathrm{d}<3 ; 0<\mathrm{RMSEA}<0.05 ; 0.97 \leq \mathrm{NNFI} \leq 1 ; 0.97 \leq \mathrm{CFI} \leq 1 ; 0.95 \leq \mathrm{GFI} \leq 1$ ve $0.95 \leq \mathrm{NFI} \leq 1$ aralıklarında olması mükemmel uyumu; $4<\mathrm{X} 2 / \mathrm{d}<5 ; \quad 0,05<\mathrm{RMSEA}<0.08$; $0.95 \leq \mathrm{NNFI} \leq 0.97 ; 0.95 \leq \mathrm{CFI} \leq 0.97 ; 0.90 \leq \mathrm{GFI} \leq 0.95$ ve $0.90 \leq \mathrm{NFI} \leq 0.95$ ise kabul edilebilir uyumu göstermektedir (Kline, 2005; Sümer, 2000). Ayrıca, ölçeğin 
güvenirliğini belirlemek amacıyla Cronbach alfa iç tutarlılık katsayısı ve test tekrar test güvenirliği hesaplanmıştır.

\section{Bulgular ve Yorum}

\section{Ölçeğin Geçerliğine İlişkin Bulgular}

\section{Dil geçerliği}

Sosyal Beceri Geliştirme Sistemi- Derecelendirme Ölçeği Öğretmen formunun Türkçeye çevrilmesi aşamasında, ölçek çevirisi birbirinden bağımsız iki uzman tarafından gerçekleştirilmiştir. Çeviriyi gerçekleştirecek olan dil uzmanlarının, her iki dilde de akıcı konuşan, ölçeğin geliştirildiği kültüre aşina, konu hakkında bilgiye sahip olması kriterleri göz önünde bulundurulmuştur. Ölçeğin çeviri aşaması tamamlandıktan sonra çeviriler arasındaki tutarlılık incelenmiş ve farklı bir uzmana ölçeğin orijinal diline çevirisi yaptırılmıştır. Geri çeviri aşamasından sonra çevirilerin uygunluğu değerlendirilmiş ve gerekli düzenlemeler yapıllmıştır. Ardından yedi öğretmenden ölçeği okuyup, herhangi bir çocuk için ölçeği doldurmaları istenmiştir. Öğretmenlerden, anlaşılması zor olan ya da anlamlı olmadığını düşündükleri maddeler için geri bildirimde bulunmaları istenmiştir. $\mathrm{Bu}$ bildirimden elde edilen bilgiler doğrultusunda ölçek maddeleri, araştırmacılar tarafından tekrar kontrol edilerek düzenlenmiştir. Verilerin analizinde pilot çalışmadan elde edilen veriler, analiz dışı bırakılmıştır.

\section{Kapsam geçerliği}

SBGS-DÖ, Sosyal Beceri ve Problem Davranışlar Ölçeğine ait kapsam geçerliğinin belirlenmesi amacıyla uzman görüşleri alınmıştır. Uzman görüşlerinin değerlendirilmesinde, her bir maddeye ait kapsam geçerliği oranı (KGO) hesaplanmıştır. Ardından, hesaplanan KGO'ların ortalaması alınarak kapsam geçerliği indeksi (KGI) belirlenmiştir. Bu indeks her bir madde için uzmanların o maddeyi gerekli görüp görmediklerinin belirlenmesinde kullanılmaktadır (Yurdugül, 2005). Bu değer, maddelerin uygunluk düzeyi için hesaplanmıştır. Uzman sayısı beş olması sebebiyle 0,99'dan büyük olan KGO değerine sahip maddelerin kapsam geçerliğinin sağlandığı sonucuna varılmaktadır (Yurdugül, 2005). KGO değerlerinin hesaplanması sonucunda, maddelerin tümünün uygunluk düzeyi için KGO 0,99 olarak hesaplanmıştır. Bu değerlerin ortalaması alınarak hesaplanan KGİ değeri de 0,99 olarak belirlenmiştir. Bu değerler ölçekteki tüm maddelerin gerekli olduğu ve kapsam geçerliğinin sağlandığını ortaya koymaktadır.

\section{Yapı geçerliği}

Ölçeğin yap1 geçerliliğinin belirlenmesinde birinci düzey doğrulayıcı faktör analizi uygulanmıştır. SBGS-DÖ, Sosyal Beceri ölçeğinin yedi boyutuna ait 46 maddelik yapısının doğrulanıp doğrulanmadığını değerlendirmek amacıyla uygulanan ilk DFA'da istatistiksel olarak anlamlı olmayan t değerine sahip maddeler 
incelenmiştir. Yapılan incelemeye göre anlamlı olmayan değere sahip hiçbir maddeye rastlanmamıştır. $\mathrm{Bu}$ nedenle tüm maddeler ölçekteki yerini korumuştur. SBGS-DÖ, Sosyal Beceri ölçeğine ait doğrulayıcı faktör analizinden elde edilen Pathdiagramı Şekil 1'de yer almaktadır.

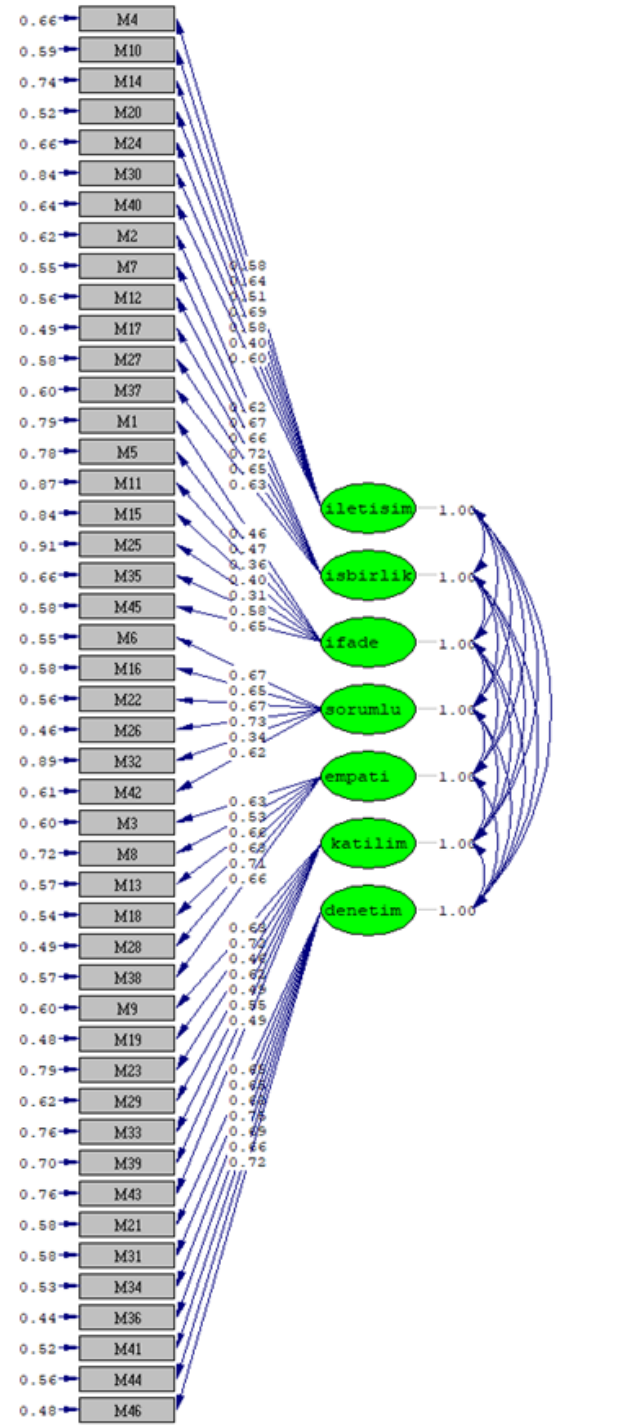

Şekil 1. Sosyal beceri geliştirme sistemi- derecelendirme ölçeği öğretmen formu sosyal beceriler ölçeği doğrulayıcı faktör analizi sonuçları 
Uyum indeksleri $\chi 2=2609.07, \mathrm{X} 2 / \mathrm{sd}=2.70, \mathrm{RMSEA}=0.070, \mathrm{CFI}=0.96, \mathrm{IFI}=0.96$, $\mathrm{NNFI}=0,96$ ve $\mathrm{NFI}=0,94$ olarak bulunmuştur. $\mathrm{Bu}$ ölçeğin faktöriyel yapısını gösteren modelin gözlenen değiş̧kenleriyle faktörleri arasındaki ilişkiyi gösteren katsayılar incelendiğinde, tüm katsayıların yeterli düzeyde olduğu sonucuna varılmıştır. DFA ile hesaplanan uyum istatistikleri dikkate alındığında, ölçeğin daha önce belirlenen yapısının toplanan verilerle yüksek düzeyde uyum sağladığına karar verilmiş̧ir.

Maddelere ait regresyon değerleri ve $t$ değerlerine Tablo 1'de yer verilmiştir. Tablo1.

Sosyal Beceri Geliştirme Sistemi- Derecelendirme Ölçeği Öğretmen Formu Sosyal Beceriler Ölçeğine Ait Regresyon ve T Değerleri

\begin{tabular}{cccccc}
\hline Maddeler & $\begin{array}{c}\text { Regresyon } \\
\text { değerleri }\end{array}$ & t değerleri & Maddeler & $\begin{array}{c}\text { Regresyon } \\
\text { değerleri }\end{array}$ & t değerleri \\
\hline M4 & 0,58 & 11,17 & M26 & 0,73 & 15,07 \\
M10 & 0,64 & 12,45 & M32 & 0,34 & 6,11 \\
M14 & 0,51 & 9,52 & M42 & 0,62 & 12,19 \\
M20 & 0,69 & 13,90 & M3 & 0,63 & 12,17 \\
M24 & 0,58 & 11,19 & M8 & 0,53 & 9,84 \\
M30 & 0,40 & 7,32 & M13 & 0,66 & 12,76 \\
M40 & 0,60 & 11,56 & M18 & 0,68 & 13,39 \\
M2 & 0,62 & 12,09 & M28 & 0,71 & 14,20 \\
M7 & 0,67 & 13,30 & M9 & 0,66 & 12,76 \\
M12 & 0,66 & 13,15 & M19 & 0,63 & 12,18 \\
M17 & 0,72 & 14,55 & M23 & 0,72 & 14,51 \\
M27 & 0,65 & 12,76 & M29 & 0,46 & 8,32 \\
M37 & 0,63 & 12,41 & M33 & 0,62 & 11,58 \\
M1 & 0,46 & 8,12 & M38 & 0,49 & 9,07 \\
M5 & 0,47 & 8,38 & M39 & 0,55 & 10,33 \\
M11 & 0,36 & 6,14 & M43 & 0,49 & 9,02 \\
M15 & 0,40 & 6,96 & M21 & 0,65 & 12,65 \\
M25 & 0,31 & 5,23 & M31 & 0,65 & 12,56 \\
M35 & 0,58 & 10,58 & M34 & 0,68 & 13,50 \\
M45 & 0,65 & 12,00 & M36 & 0,75 & 15,25 \\
M6 & 0,67 & 13,34 & M41 & 0,69 & 13,66 \\
M16 & 0,65 & 12,81 & M44 & 0,66 & 13,00 \\
M22 & 0,67 & 13,27 & M46 & 0,72 & 14,50 \\
\hline & & & & & \\
\hline & & & & \\
\hline
\end{tabular}


Tablo 1 incelendiğinde, elde edilen regresyon katsayılarının ve t değerlerinin anlamlı olduğu $(\mathrm{t}>1,92)$ ve modelin doğrulandığı belirlenmiştir.

SBGS-DÖ, Problem Davranışlar ölçeğinin beş boyutuna ait 30 maddelik yapısının doğrulanıp doğrulanmadığını değerlendirmek amacıyla DFA uygulanmıştır. Uygulanan ilk DFA'da istatistiksel olarak anlamlı olmayan t değerine sahip maddeler incelenmiştir. Yapılan incelemeye göre anlamlı olmayan değere sahip hiçbir maddeye rastlanmamıştır. Bu nedenle tüm maddeler ölçekteki yerini korumuştur. Sosyal Beceri Geliştirme Sistemi- Derecelendirme Ölçeği, Problem Davranışlar Ölçeğine ait doğrulayıcı faktör analizinden elde edilen Pathdiagramı Şekil 2'de yer almaktadır.

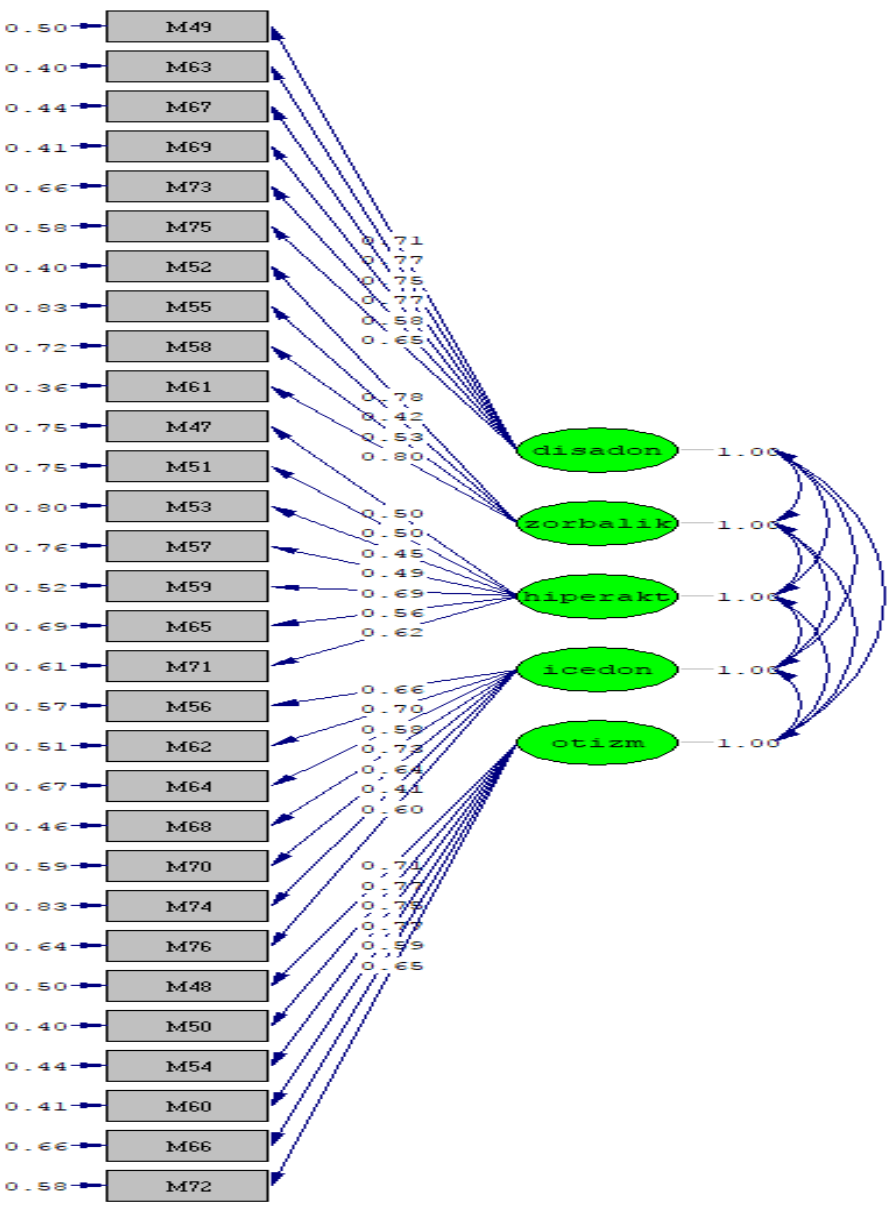

Şekil 2. Sosyal beceri geliştirme sistemi- derecelendirme ölçeği öğretmen formu problem davranışlar ölçeği doğrulayıcı faktör analizi sonuçları 
Uyum indeksleri $\chi 2=1858.92, \mathrm{X} 2 / \mathrm{sd}=4.71$, RMSEA $=0.079, \mathrm{CFI}=0.90, \mathrm{IFI}=0.91$, $\mathrm{NNFI}=0,90$ ve $\mathrm{NFI}=0,90$ olarak bulunmuştur. Bu ölçeğin faktöryel yapısını gösteren modelin gözlenen değişkenleriyle faktörleri arasındaki ilişkiyi gösteren katsayılar incelendiğinde, tüm katsayıların yeterli düzeyde olduğu sonucuna varılmıştır. DFA ile hesaplanan uyum istatistikleri dikkate alındığında, ölçeğin daha önce belirlenen yapısının toplanan verilerle yüksek düzeyde uyum sağladığına karar verilmiştir.

Maddelere ait regresyon değerleri ve $t$ değerlerine Tablo 2'de yer verilmiştir.

Tablo2.

Sosyal Beceri Geliş̧tirme Sistemi- Derecelendirme Ölçeği Öğretmen Formu Problem Davranışlar Ölçeğine Ait Regresyon ve T Değerleri

\begin{tabular}{cccccc}
\hline Maddeler & $\begin{array}{c}\text { Regresyon } \\
\text { değerleri }\end{array}$ & t değerleri & Maddeler & $\begin{array}{c}\text { Regresyon } \\
\text { değerleri }\end{array}$ & t değerleri \\
\hline M49 & 0,71 & 15,57 & M65 & 0,56 & 9,80 \\
M63 & 0,77 & 16,98 & M71 & 0,62 & 11,11 \\
M67 & 0,75 & 16,40 & M56 & 0,66 & 12,39 \\
M69 & 0,77 & 16,90 & M62 & 0,70 & 13,53 \\
M73 & 0,58 & 13,39 & M64 & 0,58 & 10,59 \\
M75 & 0,65 & 14,48 & M68 & 0,73 & 14,38 \\
M52 & 0,78 & 14,66 & M70 & 0,64 & 11,55 \\
M55 & 0,42 & 6,93 & M74 & 0,41 & 7,18 \\
M58 & 0,53 & 9,11 & M76 & 0,60 & 11,18 \\
M61 & 0,80 & 15,21 & M48 & 0,71 & 15,54 \\
M47 & 0,50 & 8,64 & M50 & 0,77 & 17,03 \\
M51 & 0,50 & 8,60 & M54 & 0,75 & 16,39 \\
M53 & 0,45 & 7,58 & M60 & 0,77 & 16,85 \\
M57 & 0,49 & 8,46 & M66 & 0,59 & 13,43 \\
M59 & 0,69 & 12,73 & M72 & 0,65 & 14,50 \\
\hline
\end{tabular}

Tablo 2 incelendiğinde, elde edilen regresyon katsayılarının ve t değerlerinin anlamlı olduğu $(\mathrm{t}>1,92)$ ve modelin doğrulandığı belirlenmiştir.

\section{Ölçeğin Güvenirliğine İlişkin Bulgular}

SBGS-DÖ Öğretmen formunun güvenirliğinin belirlenmesinde iç tutarlılık katsayısı olan Cronbach alfa hesaplanmıştır. Ayrıca test tekrar test güvenirliği için 30 çocuğa yönelik 7 öğretmen ilk uygulama gerçekleştirildikten üç hafta sonra SBGS-DÖ tekrar doldurarak iki uygulama arası korelasyon katsayılarına bakılmıştır. Tablo 3'de ölçeklere ilişkin güvenirlik katsayıları yer almaktadır. 
Tablo3.

Sosyal Beceri Geliştirme Sistemi - Derecelendirme Ölçeği Alt Boyutlarının Güvenirlik Katsayıları Sonuçları

\begin{tabular}{lcc}
\hline Alt Boyutlar & $\begin{array}{c}\text { Cronbach Alfa } \\
\text { Güvenirlik Katsayısı }\end{array}$ & Test Tekrar Test \\
\hline İletişim Alt Boyutu & .77 & .87 \\
İşbirliği Alt Boyutu & .82 & .81 \\
Kendini İfade Etme Alt Boyutu & .70 & .76 \\
Sorumluluk Alt Boyutu & .71 & .75 \\
Empati Alt Boyutu & .79 & .83 \\
Katılım Alt Boyutu & .80 & .80 \\
Öz Denetim Alt Boyutu & .86 & .85 \\
Dışsallaştırma Alt Boyutu & .82 & .86 \\
Zorbalık Alt Boyutu & .70 & .75 \\
Hiperaktivite/Dikkatsizlik Alt Boyutu & .70 & .84 \\
İçselleştirme Alt Boyutu & .77 & .79 \\
Otizm Spektrumu Alt Boyutu & .82 & .77 \\
\hline
\end{tabular}

SBGS-DÖ, Sosyal Beceri ölçeği iletişim alt boyutuna ait alfa değeri .77; işbirliği alt boyutuna ait alfa değeri .82 , kendini ifade etme alt boyutuna ait alfa değeri .70 , sorumluluk alt boyutuna ait alfa değeri .71, empati alt boyutuna ait alfa değeri olduğu .79 , katılım alt boyutuna ait alfa değeri .80 ve öz denetim alt boyutuna ait alfa değeri .86 olarak belirlenmiştir. SBGS-DÖ, Problem Davranışlar ölçeği dışsallaştırma alt boyutuna ait alfa değeri .82; zorbalık alt boyutuna ait alfa değeri .70, hiperaktivite/dikkatsizlik alt boyutuna ait alfa değeri .70, içselleştirme alt boyutuna ait alfa değeri .77 ve otizm spektrumu alt boyutuna ait alfa değeri .82 olarak saptanmıştır. Fraenkel, Wallen ve Hyun (2012) ölçeklerde yeterli sayılabilecek bir güvenirlik katsayısının en az .70 ve tercihen daha yüksek olması gerektiğini ifade etmektedir. Diğer taraftan SBGS-DÖ Öğretmen Formunda testtekrar testi sonuçları incelendiğinde test-tekrar test korelasyon değerlerinin .75ile .87 arasında değiştiği ve .70 üstünde olduğu görülmektedir. Bu sonuçlara göre Sosyal Beceri Geliştirme Sistemi- Derecelendirme Ölçeğinin, güvenirliğinin yüksek düzeyde olduğu söylenebilmektedir.

\section{Tartışma, Sonuç ve Öneriler}

Bu çalışma Gresham ve Elliot (2008) tarafından geliştirilen Sosyal Beceri Geliştirme Sistemi- Derecelendirme Ölçeği (SBGS-DÖ) Öğretmen formunun (3-5 yaş okul öncesi versiyonu) geçerlik ve güvenirlik çalışmasının yapılması amacıyla gerçekleştirilmiştir. Bu doğrultuda ölçeğin geçerliliğinin sağlanması amacıyla dil geçerliği, kapsam geçerliği ve yapı geçerliği çalışmaları yapılmıştır. Ölçeğin dil 
geçerliğinin sağlanmasında ölçek çevirisi ve geri çevirisi dil uzmanları tarafindan gerçekleştirilmiştir. Çeviri aşamaları tamamlandıktan sonra ölçeğin gerek Türk kültürüne gerekse de orijinal ölçekle olan uygunluğu değerlendirilmiş ve gerekli düzenlemeler yapılmıştır. Ölçeğe ait kapsam geçerliğinin belirlenmesi amacıyla 5 uzmandan görüşleri alınmıştır. Uzman görüşlerinin değerlendirilmesinde, her bir maddeye ait kapsam geçerliği oranı hesaplanarak, kapsam geçerliği indeksi 0,99 olarak belirlenmiştir. Bu değerlere göre ölçekteki tüm maddelerin gerekli olduğu ve kapsam geçerliğinin sağlandığı sonucuna ulaşılmıştır. Ölçeğin yap1 geçerliliğinin belirlenmesinde doğrulayıcı faktör analizi uygulanmıştır. SBGS-DÖ, Sosyal Beceri ölçeğinin yedi alt boyutuna ait 46 maddelik ve Problem Davranışlar ölçeğinin beş alt boyutuna ait 30 maddelik yapısının doğrulanıp doğrulanmadığını değerlendirmek amacıyla DFA uygulanmıştır. Uygulanan ilk DFA'da istatistiksel olarak anlamlı olmayan $t$ değerine sahip maddeler incelenmiştir. Yapılan incelemeye göre anlamlı olmayan değerlere sahip hiçbir maddeye rastlanmamıştır. Bu nedenle tüm maddeler ölçekteki yerini korumuştur. SBGS-DÖ, Sosyal Beceri ölçeğinin uyum indeksleri $\chi 2=2609.07, X 2 / \mathrm{sd}=2.70, \mathrm{RMSEA}=0.070, \mathrm{CFI}=0.96, \mathrm{IFI}=0.96, \mathrm{NNFI}=0,96$ ve NFI $=0,94$; SBGS-DÖ, Problem Davranışlar ölçeğinin uyum indeksleri ise $\chi 2=1858.92, X 2 / \mathrm{sd}=4.71, \mathrm{RMSEA}=0.079, \mathrm{CFI}=0.90, \mathrm{IFI}=0.91, \mathrm{NNFI}=0,90$ ve $\mathrm{NFI}=0,90$ olarak bulunmuştur. $\mathrm{Bu}$ ölçeğin faktöriyel yapısını gösteren modelin gözlenen değişkenleriyle faktörleri arasındaki ilişkiyi gösteren katsayılar incelendiğinde, tüm katsayıların yeterli düzeyde olduğu sonucuna varılmıştır. DFA ile hesaplanan uyum istatistikleri dikkate alındığında, ölçeğin daha önce belirlenen yapısının toplanan verilerle yüksek düzeyde uyum sağladığına karar verilmiştir.

Sosyal Beceri Geliştirme Sistemi- Derecelendirme Ölçeği Öğretmen formunun güvenirliğinin belirlenmesinde iç tutarlılık ve test tekrar test güvenirliği analizleri yapılmıştır. İç tutarlılık analizleri sonucunda SBGS-DÖ, Sosyal Beceri ölçeği iletişim alt boyutuna ait alfa değeri .77; işbirliği alt boyutuna ait alfa değeri .82, kendini ifade etme alt boyutuna ait alfa değeri .70, sorumluluk alt boyutuna ait alfa değeri .71, empati alt boyutuna ait alfa değeri olduğu .79, katılım alt boyutuna ait alfa değeri .80 ve öz denetim alt boyutuna ait alfa değeri .86 olarak saptanmıştır. SBGS-DÖ, Problem Davranışlar ölçeği dışsallaştırma alt boyutuna ait alfa değeri .82; zorbalık alt boyutuna ait alfa değeri .70, hiperaktivite / dikkatsizlik alt boyutuna ait alfa değeri .70, içselleştirme alt boyutuna ait alfa değeri .77 ve otizm spektrumu alt boyutuna ait alfa değeri .82 olarak belirlenmiştir. Orijinal ölçeğin iç tutarlılık katsayılarının ise; iletişim .84, işbirliği .89 , kendini ifade etme .83 , sorumluluk .90 , empati .86, katılım .84 ve öz denetim .86, dişsallaştırma .93, zorbalık .74, hiperaktivite / dikkatsizlik .88, içselleştirme .78 ve otizm spektrumu .84 olduğu sonucuna ulaşılmıştır (Gresham ve Elliot, 2008). Diğer taraftan SBGS-DÖ Öğretmen Formunda test-tekrar testi sonuçlarına göre test-tekrar test korelasyon değerlerinin .75 ile .87 arasında değiştiği sonucuna ulaşılmıştır. Orijinal ölçekte ise test tekrar test değerlerinin .68 ile .86 arasında değiştiği belirlenmiştir (Gresham ve Elliot, 2008). Fraenkel vd., (2012) ölçeklerde yeterli sayllabilecek bir güvenirlik katsayısının en az .70 ve tercihen daha yüksek olması gerektiğini ifade etmektedir. 
Bu doğrultuda SBGS ölçeği öğretmen formunun Türkiye'deki çocukların sosyal beceri ve problem davranışlarını değerlendirmede güvenilir bir ölçme aracı olduğu söylenebilir.

$\mathrm{Bu}$ sonuçlara göre Sosyal Beceri Geliştirme Sistemi- Derecelendirme Ölçeği Öğretmen formunun (3-5 yaş okul öncesi versiyonu) Sosyal Beceri ölçeğinin iletişim, işbirliği, kendini ifade etme, sorumluluk, empati, katılım ve öz denetim olmak üzere yedi alt boyut ve 46 maddeden; Problem Davranışlar ölçeğinin dışsallaştırma, zorbalık, hiperaktivite / dikkatsizlik, içselleştirme ve otizm spektrumu olmak üzere beş alt boyut ve 30 maddeden, genel olarak SBGS'nin 12 alt boyut ve 76 maddeden oluştuğu belirlenmiştir. Geçerlik ve güvenirlik çalışması sonucunda Sosyal Beceri Geliştirme Sistemi - Derecelendirme Ölçeği (3-5 yaş okul öncesi versiyonu) Öğretmen formunun Türkiye'deki çocukların sosyal beceri ve problem davranışlarını değerlendirmede geçerli ve güvenilir bir ölçme aracı olduğu söylenebilir.

Bundan sonra yapılacak araştırmalarda, Sosyal Beceri Geliştirme Sistemi Derecelendirme Ölçeği (3-5 yaş okul öncesi versiyonu) Aile formunun geçerlik ve güvenirlik çalışmaları yapılabilir. SBGS-DÖ öğretmen formu okul öncesi dönem çocuklarıyla çalışan öğretmenler tarafından çocukların sosyal yetersizliklerini belirlemede ve bu doğrultuda sosyal beceri eğitim programı hazırlamada kullanılabilir.

\section{Kaynakça}

Aydoğan, Y., Metin, Ş., Büyüköztürk, Ş., Mercan, Z., \& Kavak, Ş. (2017). Theinvestigation of therelationshipbetweensocialskillsand problem solvingskills of students in primaryeducationdepartment. Journal of CurrentResearches on EducationalStudies, 7(1), 161-172.

Berk, L. E. (2013). Çocuk gelişimi. (A. Dönmez Çev.). Ankara: İmge.

Broadhead, P.,Johnston, J., Tobbell, C., \&Woolley, R. (2010). Personal, socialandemotionaldevelopment. New York: Continuum International Publishing.

Brophy-Herb, H. E., Lee, R. E., Nievar, M. A., \&Stollak, G. (2007). Preschoolers' socialcompetence:

Relationstofamilycharacteristics, teacherbehaviorsandclassroomclimate. Journal of AppliedDevelopmentalPsychology, 28(2), 134-148. doi:10.1016/j.appdev.2006.12.004.

Cheung, P. P. P.,Siu, A. M. H., \& Brown, T. (2017). Measuringsocialskills of childrenandadolescents in a Chinesepopulation: Preliminary evidence on thereliabilityandvalidity of thetranslatedChineseversion of theSocialSkillsImprovementSystem-RatingScales (SSIS-RS-C). Research in DevelopmentalDisabilities, 60, 187-197. doi:10.1016/j.ridd.2016.11.019. 
Cole, D. A. (1987). Utility of confirmatoryfactoranalysis in test validationresearch. Journal of ConsultingandClinicalPsychology, 55, 584-594.

Cooper, D. H.,\&Farran, D. C. (1988). Behavioral risk factors in kindergarten. EarlyChildhoodResearchQuarterly, 3(1), 1-19. doi:10.1016/0885-2006(88)90026-9.

Cordier, R.,Speyer, R., Chen, Y.-W., Wilkes-Gillan, S., Brown, T., Bourke-Taylor, H., ... Leicht, A. (2015). Evaluatingthepsychometricquality of socialskillsmeasures: A systematicreview. PLOS ONE, 10(7), e0132299. doi:10.1371/journal.pone.0132299.

Csóti, M. (2009). Developingchildren'ssocial, emotionalandbehaviouralskills. New York: Continuum International Publishing.

Çubukçu, Z. ve Gültekin, M. (2006). İlköğretimde öğrencilere kazandırılması gereken sosyal beceriler. Ahmet Yesevi Üniversitesi Türk Dünyası Sosyal Bilimler Dergisi, 37, 155-174.

Doble, S.E.,Bonnell, J.E., \&Magill-Evans, J. (1991). Evaluation of socialskills: A survey of currentpractice. CanadianJournal of OccupationalTherapy, 58(5), 241-49.

Elliott, S. N.,Malecki, C. K., \&Demaray, M. K. (2001). New directions in socialskillsassessmentandinterventionforelementaryandmiddleschoolstudents. Exceptionality: A Special EducationJournal, 9(1-2), 19-32.

Fraenkel, J.R.,Wallen, N.E., \&Hyun, H.H. (2012). How todesignandevaluateresearch in education. New York: McGraw-Hill.

Gresham, F. M.,\&Elliott, S. N. (1990). Socialskillsratingsystem. Minneapolis, MN: PearsonAssessments.

Gresham, F. M.,\&Elliott, S. N. (2008). Socialskillsimprovementsystemratingscales. Minneapolis, MN: PearsonAssessments.

Gresham, F. M., Van, M. B., \&Cook, C. R. (2006). Socialskillstrainingforteachingreplacementbehaviors: Remediatingacquisitiondeficits in $\begin{array}{llll}\text { at-risk } \quad \text { students. } & \text { BehavioralDisorders, }\end{array}$ doi:10.1177/019874290603100402.

Güral, M.,\& Önder, A. (2015). Televizyon izleme süresinin okul öncesi eğitim kurumuna devam eden 60-72 aylık çocukların sosyal becerileri üzerindeki etkisinin incelenmesi. TurkishStudies, 10(7), 467-488.

Güral, M., Sezer, T., Güven, G., \& Efe Azkeskin, K. (2013). Investigation of therelationshipbetweensocialskillsand self-managementbehaviors of 5 yearoldchildren. Journal of EducationalandInstructionalStudies in The World, 3(1), 53-62.

Haager, D.,\&Vaughn, S. (1995). Parent, teacher, peer, and self- reports of thesocialcompetence of studentswithlearningdisabilities. Journal of Learning Disabilities, 28(4), 205-215. 
Hupp, S. D.A.,LeBlanc, M., Jewell, J. D., \&Warnes, E. (2009). HistoryandOverview. J. L. Matson (Ed.) Socialbehaviorandskills in children içinde (s. 1-21). New York: Springer.

Kettler, R. J.,Elliott, S. N., Davies, M., \&Griffin, P. (2011). Testing a multistagescreeningsystem: Predictingperformance on Australia'snationalachievement test usingteachers' ratings of academicandsocialbehaviors. School Psychology International, 33(1), 93-111. doi:10.1177/0143034311403036.

Kline, R.B. (2005). Principlesandpractice of structuralequationmodeling (2nd Edition ed.). New York: TheGuilfordPress.

Kwon, K., Kim, E. M., \&Sheridan, S. M. (2012). A contextualapproachtosocialskillsassessment in thepeergroup: Who is thebestjudge? School PsychologyQuarterly, 27(3), 121-133. doi10.1037/a0028696.

Leff, S.,\& Lakin, R. (2005). Playground-basedobservationalsystems: A reviewandimplicationsforpractitionersandresearchers. School PsychologyReview, 34(4), 475-89.

Lim, S. M.,\&Rodger, S. (2008). An occupationalperspective on theassessment of socialcompetence in children. British Journal of OccupationalTherapy, 71(11), 469-481. doi:10.1177/030802260807101104.

Luiselli, J. K.,McCarty, J. C., Coniglio, J., Zorilla-Ramirez, C., \&Putnam, R. F. (2005). Socialskillsassessmentandintervention. Journal of Applied School Psychology, 21(1), 2138. doi:10.1300/j370v21n01_02.

Mathieson, K. (2005). Socialskills in theearlyyears: Supportingsocialandbehaviourallearning. London: Paul Chapman Publishing.

McClelland, M. M.,\&Morrison, F. J. (2003). Theemergence of learning-relatedsocialskills in preschoolchildren. EarlyChildhoodResearchQuarterly, 18(2), 206-224. doi:10.1016/s0885-2006(03)00026-7.

McClelland, M. M.,Morrison, F. J., \&Holmes, D. L. (2000). Children at risk forearlyacademicproblems: The role of learning-relatedsocialskills. EarlyChildhoodResearchQuarterly, 15(3), 307-329.

Merrell, K. W. (2001). Assessment of children'ssocialskills: Recentdevelopments, bestpractices, andnewdirections. Exceptionality, 9(1-2), 318.doi:10.1080/09362835.2001.9666988.

Schaefer, B. A.,Shur, K. F., Macri-Summers, M., \&MacDonald, S. L. (2004). Preschool children'slearningbehaviors, conceptattainment, socialskills, and problem behaviors: Validityevidenceforpreschoollearningbehaviorsscalescores. Journal of PsychoeducationalAssessment, 22(1), 15-32. doi:10.1177/073428290402200102. 
Sümer, N. (2000). Yapısal eşitlik modelleri: Temel kavramlar ve örnek uygulamalar. Türk Psikoloji Yazılarl, 3(6), 49-74.

Swale, J. (2006). Settingthesceneforpositivebehaviour in theearlyyears: A frameworkforgoodpractice. New York: Routledge.

Warnes, E. D.,Sheridan, S. M. Geske, J., \&Warnes, W. A. (2005). A contextualapproachtotheassessment of socialskills: Identifyingmeaningfulbehaviorsforsocialcompetence. Psychology in the Schools, 42(2), 173-187. doi: 10.1002/pits.20052.

Yurdugül, H. (2005). Ölçek geliştirme çalışmalarında kapsam geçerliği için kapsam geçerlik indekslerinin kullanılması. XIV. Eğitim Bilimleri Kurultayı, 28-30 Eylül, Pamukkale Üniversitesi, Denizli.

\section{Extended Abstract}

Social skills are very important in the development of children and that children have increased their academic achievement as well as early learning skills, reduced problem behaviors, and positively affected children's self-esteem.In this context, it is thought that it is important to provide a measuring instrument to the early childhood education field in order to evaluate social skills and problem behaviors of children, to evaluate the social skills and problem behaviors of children with this measurement and to provide necessary support to children for these evaluations.In this study, it is aimed to conduct the validity and reliability study of the Social Skills Improvement System- Rating Scale (3-5 age preschool version) teacher form.

The sample of the research consists of teachers $(n=28)$ of 305 children in the 3 5 year old group who continued to different pre-school education institutions. The Social Skills Improvement System- Rating Scale (3-5 age preschool version) teacher form developed by Gresham and Elliott (2008) was used as data collection tool in the research.The Social Skills Improvement System- Rating Scale (SSIS-RS) is an important and comprehensive revision of the Social Skill Rating System (SSRS) developed by Gresham and Elliott in 1990.The Social Skills Improvement SystemRating Scale can be used for pre-school (aged 3-5 years), primary school (ages 612 ), and secondary education (ages 13-18).It was designed to facilitate the universal screening of students at risk of developing social behavior difficulties, to help plan interventions for improvingthese behaviors, and to evaluate progress on targeted skills after intervention.

The Social Skills Improvement System- Rating Scale pre-school (3-5 years) teacher form used in this study consists of 76 itemsand two scale domains: Social Skills and Problem Behaviors. The Social Skills domains made up of seven subscales: Communication, Cooperation, Assertion, Responsibility, Empathy, Engagement, and Self-control. The Problem Behaviors domain has five subscales: Externalizing, Bullying, Hyperactivity/Inattention, Internalizing, and Autism 
Spectrum. The two scale domains are rated on a four-point Likert rating scale $(0=$ Never, 1 = Sometimes, 2 = Often, 3 = Almost always)indicating how frequently the teacher think children exhibit each social skill and/or problem behavior item. Social skillsare additionally rated on a three-point Likert rating scale $(0=$ Not important, 1 $=$ Important, 2 = Critical) that indicates howimportant the teacher think the social skill items are for children. Examples of social skills subscale items include "takesturn in conversations," "makes eye contact when talking," "shows concern for others," and "feels bad when others are sad."Examples of problem behavior subscale items include "disobeys rules or requests," "fights with others," "fidgets or movesaround too much," and "acts anxious with others"

Content validity, confirmatory factor analysis, test retest reliability and internal consistency coefficient (Cronbach alpha) were calculated in the analysis of the data.Five experts were consulted for the content validity and 76 items on the scale were decided by the experts to remain on the scale. As a result of confirmatory factor analysis, it was determined that 76 items and 12 factorial structure of the scale generally comply with the collected data. As a result of the internal consistency analysis, the Social Skills Improvement System-Rating Scale, the alpha value of the Social Skill Scale communication subscale .77; the alpha value of the cooperation subscale .82 , the alpha value of the assertion subscale .70 , the alpha value of the responsibility subscale .71 , the alpha value of the empathy subscale .79 , the alpha value of the engagement subscale.80, the alpha value of the self-controlsubscale was .86. SSIS-RS, alpha value of the Problem Behavior scale externalizing subscale .82; the alpha value for bullying subscale .70, the alpha value for hyperactivity/inattention subscale .70, the alpha value for internalizing subscale .77, and the alpha value for autism spectrum subscale .82 . On the other hand, the result of the test-retest correlation in the Social Skills Improvement System- Rating Scale Teacher Form has been changed from .75 to .87 in the test-retest correlation values.These results showed that The Social Skills Improvement System- Rating Scale (3-5 Age Preschool Version) Teacher Form a reliable and valid tool for measuring social skills of children in Turkey.

In future researches, The Social Skills Improvement System- Rating Scale (3-5 age preschool version) can be used to study the validity and reliability of the parent form.The Social Skills Improvement System- Rating Scale teacher form can be used by teachers working with pre-school children to determine the social inadequacy of children and to prepare a social skills training program in this direction. 